\title{
The Impact of a Warm Ocean Eddy on Typhoon Morakot (2009): A Preliminary Study from Satellite Observations and Numerical Modelling
}

\author{
I-I Lin ${ }^{1, *}$, Ming-Dah Chou ${ }^{2}$, and Chun-Chieh Wu ${ }^{1}$ \\ ${ }^{1}$ Department of Atmospheric Sciences, National Taiwan University, Taipei, Taiwan \\ ${ }^{2}$ Department of Atmospheric Sciences, National Central University, Jhongli, Taiwan
}

Received 28 February 2011, accepted 19 August 2011

\begin{abstract}
On 6 August 2009, typhoon Morakot encountered a giant warm ocean eddy approximately $700 \mathrm{~km}$ by $500 \mathrm{~km}$ in the southern eddy rich zone of the western North Pacific Ocean. Soon after passing over the warm ocean eddy, Morakot reached its peak intensity at category 2 . Results based on multiple satellite observations and numerical modelling suggest very favourable ocean conditions provided by the warm ocean eddy during this earlier developmental stage of Morakot. It is found that in the presence of the observed warm ocean eddy, the upper ocean heat content increased significantly by $\sim 100 \%$, from $\sim 60$ to $120 \mathrm{KJ} \mathrm{cm}^{-2}$. This very deep and warm subsurface temperature effectively reduced the negative feedback of typhoon-induced ocean cooling. As a result, the during-storm sea surface temperature remained high at $\sim 29-30^{\circ} \mathrm{C}$. This very warm duringtyphoon sea surface temperature (SST) provided an increase in air-sea enthalpy flux supply by $\sim 200 \%$ (i.e., $\sim 500 \mathrm{~W} \mathrm{~m}^{-2} \mathrm{under}$ the warm eddy situation .vs. the $\sim 170 \mathrm{~W} \mathrm{~m}^{-2}$ under the without eddy situation). Also, since the during-typhoon SST remained high, the moisture supply was increased to enhance convective activities. Numerical experiments using the Weather Research and Forecasting (WRF) model suggest that the presence of the warm ocean eddy does not change the overall structure or characteristics of Morakot. Rather, it contributes to a 10\% increase in Morakot's precipitation. This research shows that in addition to the favourable atmospheric conditions such as the Intra-Seasonal Oscillation or the southwestern monsoon flow, there also exist favourable ocean conditions provided by the presence of a warm ocean eddy during the early developmental stage of Morakot. Further studies based on a full-physics typhoon-ocean coupled model are needed to quantify the role of the upper ocean features in affecting the evolution of Morakot, including its rainfall over Taiwan.
\end{abstract}

Key words: Warm ocean eddy, Morakot's rainfall

Citation: Lin, I. I., M. D. Chou, and C. C. Wu, 2011: The impact of a warm ocean eddy on Typhoon Morakot (2009): A preliminary study from satellite observations and numerical modelling. Terr. Atmos. Ocean. Sci., 22, 661-671, doi: 10.3319/TAO.2011.08.19.01(TM)

\section{INTRODUCTION}

\subsection{Motivation}

The rainfall associated with typhoons, while affected by the high mountains, is the most critical to research and forecast challenges in Taiwan (Wu and Kuo 1999; Wu 2001; Wu et al. 2002; Alpers et al. 2007, 2010). In 2009, Typhoon Morakot passed over Taiwan and became one of the deadliest typhoons in Taiwan's historical record. In August 2009, Morakot devastated southern Taiwan with its record-breaking torrential rain of $\sim 1400 \mathrm{~mm}$ in $24 \mathrm{~h}$ (Hong et al. 2010; Huang et al. 2011; Tao et al. 2011; Yang et al. 2011; Yen et al. 2011). Together with the associated massive

\footnotetext{
* Corresponding author

E-mail:iilin@as.ntu.edu.tw
}

mudslide, Morakot buried an entire village claiming 500 lives, and resulted in change of the governmental cabinet. Just prior to its landfall, Morakot encountered a giant warm ocean eddy approximately $700 \mathrm{~km}$ by $500 \mathrm{~km}$. After the encounter, Morakot's intensity reached its peak and made landfall in $6 \mathrm{~h}$ (Fig. 1). This motivates us to explore the role this giant warm ocean eddy played in Morakot, especially as many studies focus on atmospheric influences with regard to Morakot (Hong et al. 2010; Huang et al. 2011; Tao et al. 2011; Yang et al. 2011; Yen et al. 2011). As the ocean is the energy and moisture source for typhoons, it is thus desirable to conduct an investigation from an oceanographic perspective. Especially cyclone-ocean interaction is an 


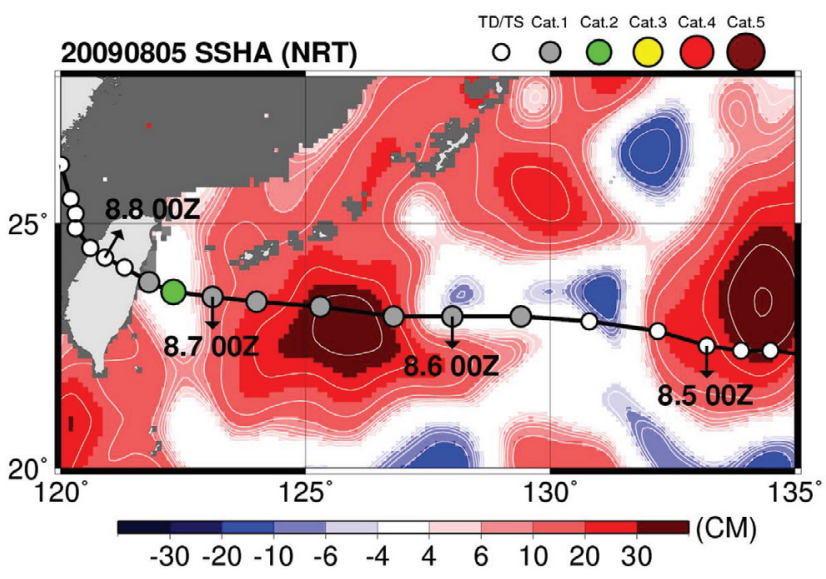

Fig. 1. SSHA map based on satellite altimetry observation showing the locations of the two prominent warm ocean eddies (characterized by +SSHA of 10 - $40 \mathrm{~cm}$ ) with Morakot's track over-plotted.

ongoing critical scientific issue and large international field programmes were conducted recently to explore this problem in the Pacific (D'Asaro et al. 2011; Pun et al. 2011).

In this study, we first introduce the oceanographic setting and origin of the eddy in the western North Pacific. In section 2, the data and method are presented. The observational and numerical-simulation results are shown in sections 3 and 4, respectively. In section 5, the discussion and conclusions are presented.

\subsection{Oceanographic Setting and Origin of the Eddy in the Western North Pacific}

The Western North Pacific (WNP) is a vast and complex ocean. In addition to the Kuroshio warm current, there are two eddy-rich zones (ERZ) which have frequent occurrences of mesoscale anti-cyclonic and cyclonic ocean eddies (Qiu 1999; Roemmich and Gilson 2001; Hwang et al. 2004; Lin et al. 2005; Chen et al. 2007). These dynamic ocean features are usually more difficult to observe by sea surface temperature (SST) measurements but can be effectively observed from satellite altimetry (Qiu 1999; Shay et al. 2000; Goni and Trianes 2003; Lin et al. 2005; Goni et al. 2009).

As observed by satellite altimeters, regions west of the dateline (i.e., the WNP region) have much larger variability in sea surface height anomalies (SSHA) as compared to regions east of the dateline. The WNP north of the $35^{\circ} \mathrm{N}$ latitude and southeast of Japan is the northern eddy-rich zone (NERZ). Eddies in the NERZ are Kuroshio extension eddies (or rings), they are similar to the Gulf Stream rings in the Atlantic, i.e., and originate from western boundary currents (Yasuda 1992). The WNP south of $22^{\circ} \mathrm{N}$ latitude is the southern eddy-rich zone (SERZ). According to Qiu (1999), the SERZ eddies originate from the baroclinic instability of the weak flow between the westward North Equatorial Current and the eastward Subtropical Countercurrent. SERZ ed- dies are westward propagating eddies and have a lifetime of 200 days (Lee et al. 2003; Hwang et al. 2004).

As the SERZ located amidst the frequent passages of typhoons, there are frequent interactions between eddies and typhoons (Lin et al. 2005, 2008). Based on 13 years' of observations and numerical modelling, it has been found that warm ocean eddies in the SERZ are critical to the Western North Pacific super-typhoons (typhoons of maximum sustained 1-minute surface wind speed exceeding $130 \mathrm{kts}$ ) (Lin et al. 2005, 2008).

\section{DATA AND METHOD}

In this work, the intensity and track data of Morakot is from the best track database of the US Joint Typhoon Warning Center (JTWC). In addition, three types of satellite observational data and three models are used for analysis. Satellite observational data include: (1) SST data from the cloud-penetrating microwave TRMM (Tropical Rainfall Measuring Mission), TMI (TRMM Microwave Imager) and AMSR-E (Advanced Microwave Scanning Radiometer) sensors (Wentz et al. 2000). (2) SSHA data from the JASON-1, ENVISAT, and GFO (GEOSAT Follow-On) satellite altimeters (Fu et al. 1994; Fu and Cazenave 2001) (data source: delayed mode product from the Ssalto/Duacs and distributed by Aviso). The SSHA data is used for ocean eddy identification and derivation of upper ocean thermal structure, which are then used as input for model simulations. (3) The $85 \mathrm{GHz} /$ horizontal polarization brightness temperature (Tb) data (Kelvin) from the SSMI (Special Sensor Microwave Imager) sensor are used for observation of convective activities (Kidder and Vonder Haar 1995).

The three models used are introduced below. The first model is a two-layer reduced gravity ocean model developed by Shay et al. (2000). This model is used to derive the upper ocean subsurface thermal structure using satellite altimetry SSHA observations. It is well known that in addition to SST, ocean subsurface thermal structure information (typically from the surface down to $200 \mathrm{~m}$ ) is critical for the development of tropical cyclones (Holliday and Thompson 1979; Emanuel 1999; Shay et al. 2000; Emanuel et al. 2004; Lin et al. 2005, 2008, 2009a, b; Goni et al. 2009; Price 2009); however, it was not possible to routinely obtain such information over the vast oceans till the launch of the TOPEX/Poseidon satellite altimeter in 1993 (Fu et al. 1994). Using input of the observed SSHA to the two-layer reduced gravity model (Shay et al. 2000; Pun et al. 2007), it is now possible to derive subsurface ocean thermal structure to a first order in an operational basis. Using this model, the depth of the 20 degree isotherm (D20) and the 26 degree isotherm (D26) can be derived. The accuracy of this model in the western North Pacific has been extensively validated using more than 5000 in situ upper ocean thermal structure profiles from the Argo floats (Pun et al. 2007). It has been 
found that this model is applicable in the region covering $10-26^{\circ} \mathrm{N}$ and $120-170^{\circ} \mathrm{E}$. Thus, it is usable for the case of Morakot (Fig. 1). The derived D26 can then be used together with the observed SST to calculate the upper ocean heat content (or tropical cyclone heat potential, TCHP) (Shay et al. 2000; Goni and Trinanes 2003; Pun et al. 2007; Lin et al. 2008, 2009a, b; Goni et al. 2009).

The second model used is a 1-D ocean mixed layer model after Melor and Yamada (1982). This model is used to simulate the during-typhoon SST and subsurface thermal structure profiles (Price 1981; Mellor and Yamada 1982; Lin et al. 2003a, b, 2008, 2009a, b). Though SST and upper ocean thermal structures are critical information for tropical cyclones, at the moment it is only possible to obtain such information before or after a typhoon's passing using satellite observations (Emanuel 1999; Lin et al. 2003a, b, 2008, 2009a, b; Black et al. 2007). Due to the presence of rain and clouds, it is not possible to obtain the during-typhoon SST and subsurface thermal structure using satellite observations (Kidder and Vonder Haar 1995; Wentz et al. 2000; Lin et al.2005). It is therefore necessary to use the satelliteobserved pre-typhoon SST and subsurface profiles as input to the ocean mixed layer model to simulate the duringtyphoon SST and subsurface thermal structure. This ocean mixed layer model is run according to Moarakot's wind speed and translation speed. Details of the model set up can be found in Lin et al. (2008).

The third model is the WRF full-physics atmospheric model. Since the most damaging aspect of Morakot was its rainfall, this model is used to assess the role the observed warm ocean eddy played in Morakot's convective activities (Hong et al. 2010; Huang et al. 2011; Tao et al. 2011; Yang et al. 2011; Yen et al. 2011). In current literature, there exist quite a number of studies exploring the role warm ocean features or eddies which play a role in a tropical cyclone's intensity (Hong et al. 2000; Goni and Trinanes 2003; Lin et al. 2005, 2008, 2009b; Wu et al. 2007; Goni et al. 2009). In contrast, very little is done to investigate the possible role ocean features or eddies played in a cyclone's rainfall discharge. Therefore, two series of simulations based on the 'with eddy-encountering' and 'without eddy-encountering' simulations are performed to delineate the role the observed warm ocean eddy played in Morakot's rainfall. As the focus is to compare the impact of different ocean conditions on Morakot's rainfall, the initial atmospheric conditions for the two simulations are fixed. The simulations were performed between 5 and 8 August 2009.

The WRF is not a coupled atmosphere and ocean model. In order to have an accurate representation of the duringtyphoon ocean condition for the simulation, the SST input is updated each day as follows. On 5 August when Morakot and its ocean interaction was weak (i.e., TS category), the SST input was based on the observed SST on 5 August using the satellite AMSR-E and TMI observations. As the typhoon-ocean interaction became stronger when Morakot intensified to category- 2 between 6 and 8 August, the ocean subsurface impact to SST has to be included (Price 1981; Lin et al. 2005, 2008). During this period, the 'T100' SST, as proposed by Price 2009 was used. This is because the intense typhoon wind turbulence caused subsurface water to surface and created a well-mixed layer with uniform temperature from surface to the mixed layer depth (Price 1981; Lin et al. 2003a, b; Tseng et al. 2010; Lin 2012). According to Price 2009, for a moderate typhoon travelling at a moderate translation speed, the during-typhoon mixing depth is typically around $50-100 \mathrm{~m}$. As such, the depth-averaged temperature from the surface to a 50 - $100 \mathrm{~m}$ depth, i.e., T50 or T100, can be a good characterisation for the duringtyphoon SST (Price 2009). As the mixing increases with the time of the typhoon's passing, T50 was used as input for 6 August while T100 was used for 7 and 8 August. For the 'with eddy' run, during-typhoon T50 and T100 were estimated based on the altimetry-derived pre-typhoon upper ocean thermal structure using the two-layer reduced gravity ocean model developed by Shay et al. (2000) (Pun et al. 2007; Goni et al. 2009). For the 'without eddy' run, the during-typhoon T100 was estimated based on the climatological upper ocean thermal structure profile from the WOA (World Ocean Atlas) data base.

\section{RESULTS BASED ON SATELLITE OBSERVA- TIONS}

Figure 2 depicts the ocean pre-conditions in D26, TCHP, and SST as observed on 4 August 2009. It can be seen that Morakot was travelling on the SERZ and it encountered two warm ocean eddies of SSHA of +10 to $+40 \mathrm{~cm}$ (Fig. 1). As reported by Lin et al. (2005, 2008); warm ocean eddies are usually characterised by a SSHA of more than $+6 \mathrm{~cm}$ and eddies of such high +SSHA of $10-40 \mathrm{~cm}$ are very prominent warm ocean eddies. As shown in Fig. 1, Morakot passed over the first warm eddy during its genesis period as a tropical depression and later as a tropical storm during 0600 UTC 4 August - 0600 UTC 5 August 2009. At 1800 UTC 5 August it became a category-1 typhoon, and soon at 0900 UTC 6 August it encountered the second warm ocean eddy (Figs. 1 and 2). It continued to intensify over this warm eddy and soon after eddy-encounter, it reached its peak of category-2 at 0600 UTC 7 August (Fig. 1). It then made landfall at 1200 UTC 7 August.

As shown in Figs. $2 \mathrm{a}$ and $\mathrm{b}$, over the warm eddy region, the subsurface warm layer (characterised by D26) is much deeper and heat content is much higher, as compared to the ambient waters. As in Fig. 2b, in the warm ocean eddy regions, the D26 is as high as 90 - $110 \mathrm{~m}$ while the ambient D26 was only around 40 - $60 \mathrm{~m}$, i.e., an increase of D26 by $\sim 100 \%$ in the warm eddy regions. A similar situation is found in the upper ocean heat content (or TCHP) wherein 

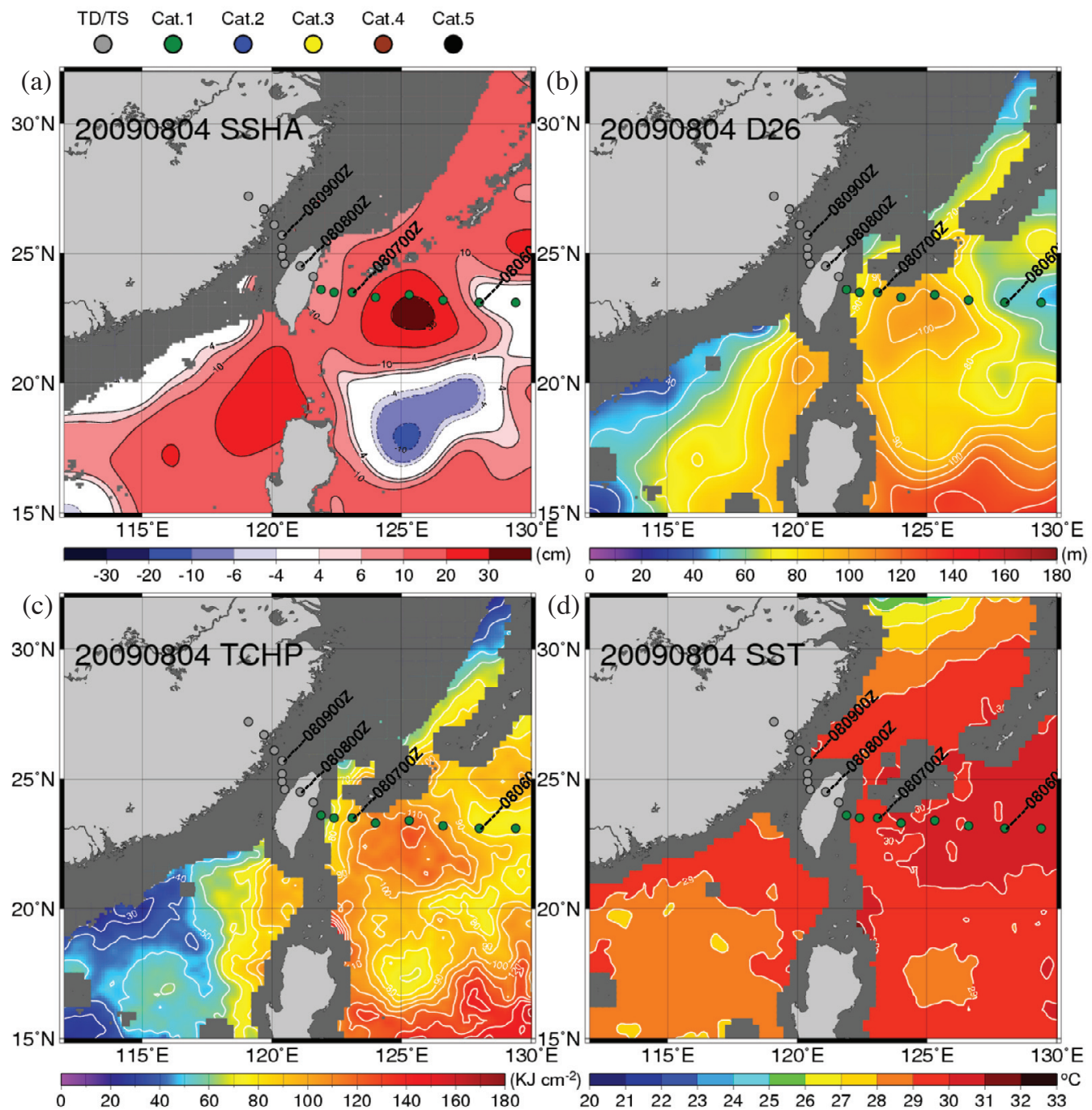

Fig. 2. Ocean pre-condition in SSHA (a), D26 (b), TCHP (c), and SST (d) for the case of Morakot as observed on the $4^{\text {th }}$ of August 2009 . The track of Morakot is over-laid.

a very high TCHP of $\sim 100-130 \mathrm{KJ} \mathrm{cm}^{-2}$ was observed in the eddy regions while the TCHP outside the eddy regions was only around $50-70 \mathrm{KJ} \mathrm{cm}^{-2}$ (Fig. 2c). According to Lin et al. $(2005,2008,2009 a)$, these are very high values of D26 and TCHP favouring typhoons and well-above most observed D26 and TCHP values over the global cyclone basins (Goni and Trinanes 2003; Goni et al. 2009).

The SST situation (Fig. 2d) is consistent with the TCHP observations such that a very warm SST, especially over the warm ocean eddy regions were observed. In the warm ocean eddy regions, the observed SST consisted of genuinely high values of $\sim 30-31^{\circ} \mathrm{C}$. Although the ambient SST was slightly lower, the SST of $\sim 29-30^{\circ} \mathrm{C}$ was still high and favourable for typhoon intensification.

Observing the SSMI $85 \mathrm{GHz}$ Tb maps at 0907 UTC on 5 August (Fig. 3a), the asymmetric convection of Morakot can be seen, with much pronounced activity at the south of the storm. As Morakot encountered the second warm eddy, increase in the convective activity was observed. As in Fig. 3b, it can be observed that the convective activities were much stronger, covering a wider region, and with enhanced activities at the over-lapping region of the warm eddy and Morakot. This situation persisted as Morakot left the warm eddy and reached its peak, just before its landfall (Fig. 3c).

\section{RESULTS BASED ON NUMERICAL MODEL- LING}

Using the two-layer reduced gravity ocean model with the observed SSHA as input, the subsurface D20 and D26 were derived (Shay et al. 2000; Goni and Trinanes 2003; Pun et al. 2007). Figure 4 illustrates the derived upper ocean thermal profile in the centre of the warm ocean eddy (graysolid profile), as compared to the climatological profile (black-solid profile, based on the NOAA World Ocean Atlas 2001 database, Stephens et al. 2002) showing the 'without 
(a) $08 / 05 / 09$ 0600 Z O9W MORAKO

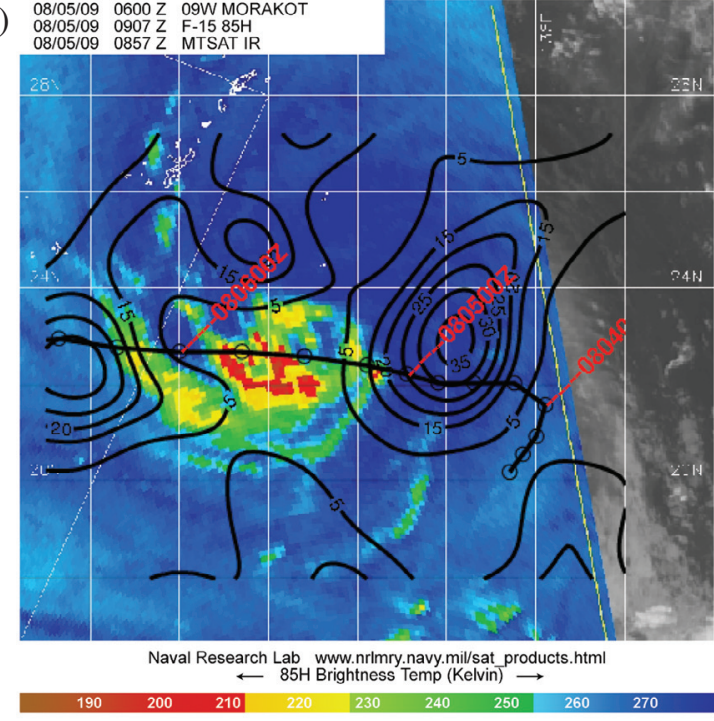

(b)

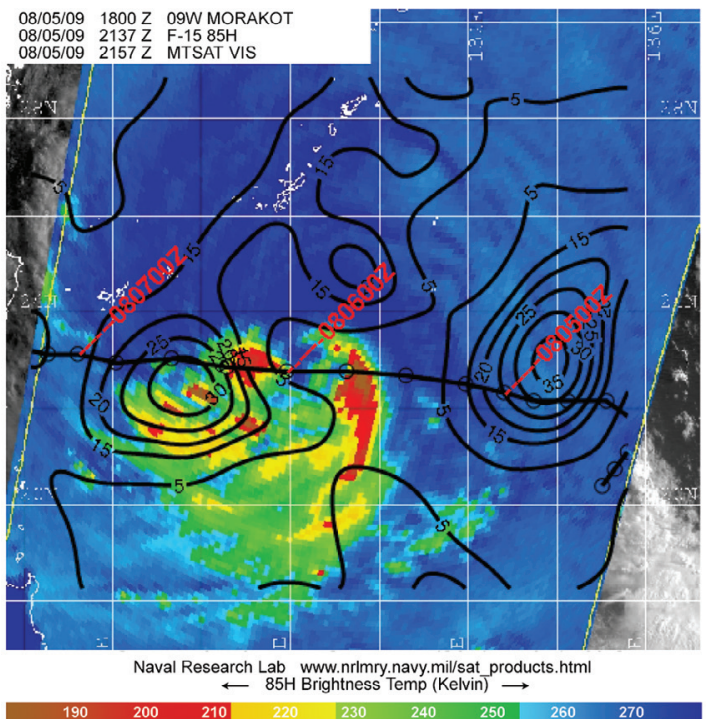

(c)

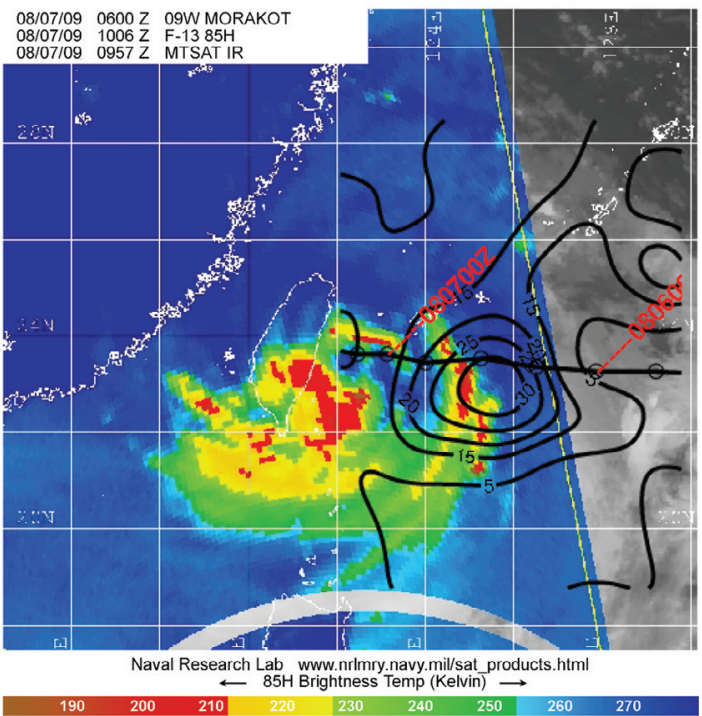

Fig. 3. $85 \mathrm{GHz} /$ horizontal polarization $\mathrm{Tb}$ of the SSMI at (a) 0907 UTC (5 August), (b) 2137 UTC (5 August), and (c) 1006 UTC (7 August). The black contours are the SSHA from Fig. 1, showing the location of the warm ocean eddies.

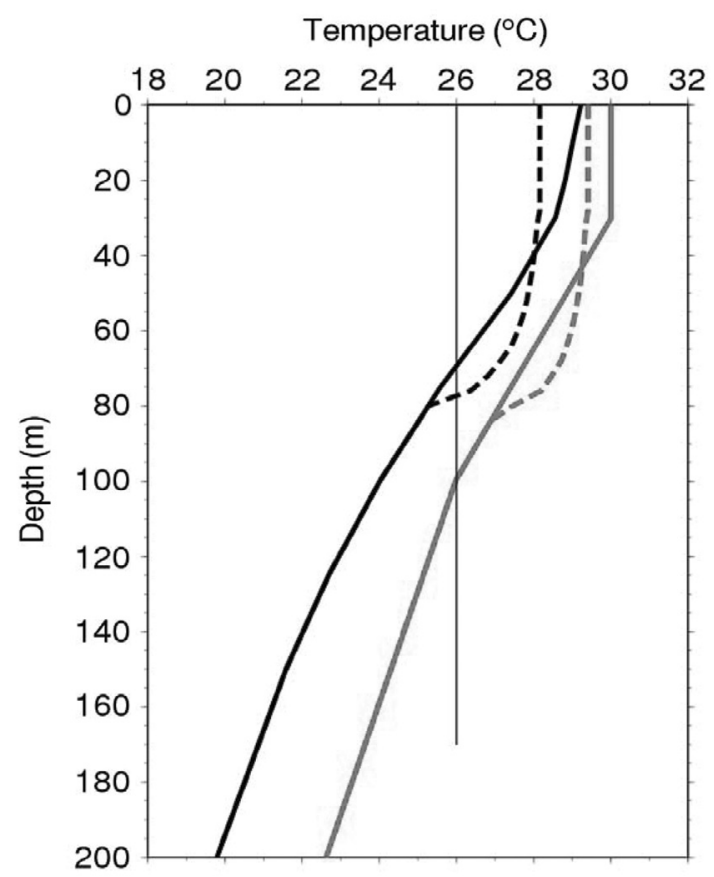

Fig. 4. Gray-solid profile: pre-typhoon ocean-depth temperature profile at the eddy centre derived from the 2-layer reduced gravity model (Shay et al. 2000) using input from the observed SSHA and SST. Graydash profile: during-storm depth-temperature profile simulated by the mixed layer model of Mellor and Yamada (1982). Black-solid profile: climatological ocean-depth temperature profile showing the "without eddy' condition. Black-dash profile: mixed-layer model simulated during-storm ocean profile under the 'without eddy' condition.

eddy' upper ocean thermal condition. Clearly, the presence of the observed warm eddy greatly deepens the subsurface warm layer, with D26 reaching $105 \mathrm{~m}$ (gray-solid profile). Without the presence of an eddy, the climatological D26 was only around $65 \mathrm{~m}$ (black-solid profile). As for the SST, the climatological SST was $\sim 29.2^{\circ} \mathrm{C}$ while the warm eddy SST was $\sim 30^{\circ} \mathrm{C}$ (Fig. 4).

These 2 profiles are then used as initial profiles to the 1-D mixed layer model (Mellor and Yamada 1982) to simulate the during-storm upper ocean thermal structure. The model was run according to Morakot's translation speed and wind speed. The drag coefficient $(C d)$ was the highwind coefficient based on Powell et al. (2003). Figure 4 presents the results. It can be found that due to the weak wind of Morakot and the deep subsurface warm layer in the warm ocean eddy, little ocean cooling could be induced by a typhoon and the during-storm SST was still around $29.2^{\circ} \mathrm{C}$ (gray-dashed profile). Under the 'without eddy run', a stronger ocean response is found with during-storm SST of $28^{\circ} \mathrm{C}$ (black-dashed profile).

With the simulated upper ocean thermal profiles under the two scenarios, the during-storm air-sea enthalpy fluxes (latent + sensible heat fluxes, Emanuel 1995) could be estimated using the bulk aerodynamic formulae (Black et al. 2007; Lin et al. 2008, 2009a). The atmospheric boundary 
condition used was from the ERA-40 reanalysis data of the European Centre for Medium Range Weather Forecasts (ECMWF). As summarized in Table 1, there was a much more air-sea flux supply under the warm ocean eddy condition and the estimated enthalpy flux was $\sim 545 \mathrm{~W} \mathrm{~m}^{-2}$. Without the warm ocean eddy, there was a much less enthalpy flux supply, typically $\sim 170 \mathrm{~W} \mathrm{~m}^{-2}$ (Table 1 ).

Using the WRF model, the impact of the warm eddy on Morakot's rainfall was estimated under the 'with warm ocean eddy' and 'without warm ocean eddy' scenarios, as described in section 2 . Figure 5 depicts the difference in the

Table 1. Estimated air-sea sensible, latent heat and total enthalpy fluxes under the 'with eddy' and 'without eddy' conditions.

\begin{tabular}{cccc}
\hline $\mathbf{W ~ m ~}^{-2}$ & SHF & LHF & Total \\
\hline With eddy & 27 & 518 & 545 \\
No eddy & -55 & 230 & 175 \\
\hline
\end{tabular}
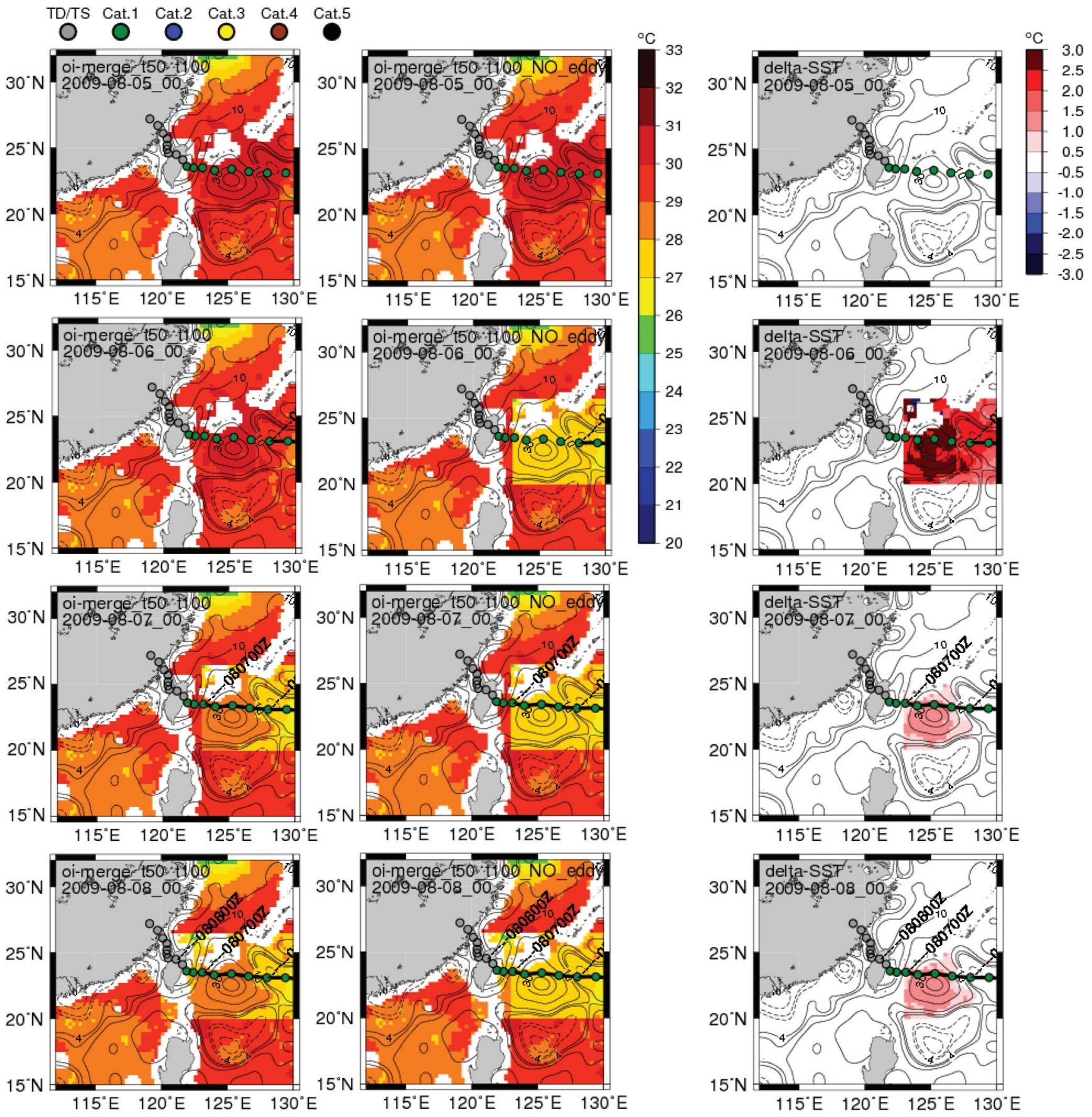

Fig. 5. Comparison between the SST input for the 'with eddy' and 'without eddy' runs of the WRF simulations between 5 - 8 August 2009. 
SST input for the 2 scenarios. One can see that under the 'with eddy' scenario (left column), the SST could remain high as compared to the 'without eddy' scenario (middle column) and the difference in SST is typically between $1-2^{\circ} \mathrm{C}$. As observed in the corresponding near surface $(2 \mathrm{~m})$ water vapour mixing ratio, there was more water vapour supply under the 'with eddy' scenario, especially between $6-7 \mathrm{Au}-$ gust (Fig. 6) when Morakot passed through the warm ocean eddy. Typically, the increase was about $1-3 \mathrm{~g} \mathrm{~kg}^{-1}$, i.e., a 5 -
$12 \%$ increase to the total vapour supply of $\sim 22-25 \mathrm{~g} \mathrm{~kg}^{-1}$.

Observing the corresponding rainfall amount, one can see the corresponding increase in precipitation (Fig. 7). As Morakot passed over the warm eddy on $6^{\text {th }}$ August, increase in precipitation by $5-30 \mathrm{~mm}$ was observed. This also corresponds to about a $10 \%$ increase of the total precipitation of between $30-120 \mathrm{~mm}$. From August $7^{\text {th }}$ to $8^{\text {th }}$ as Morakot progressed towards Taiwan, an increase in precipitation, with an enhancement over the southern half of the storm,

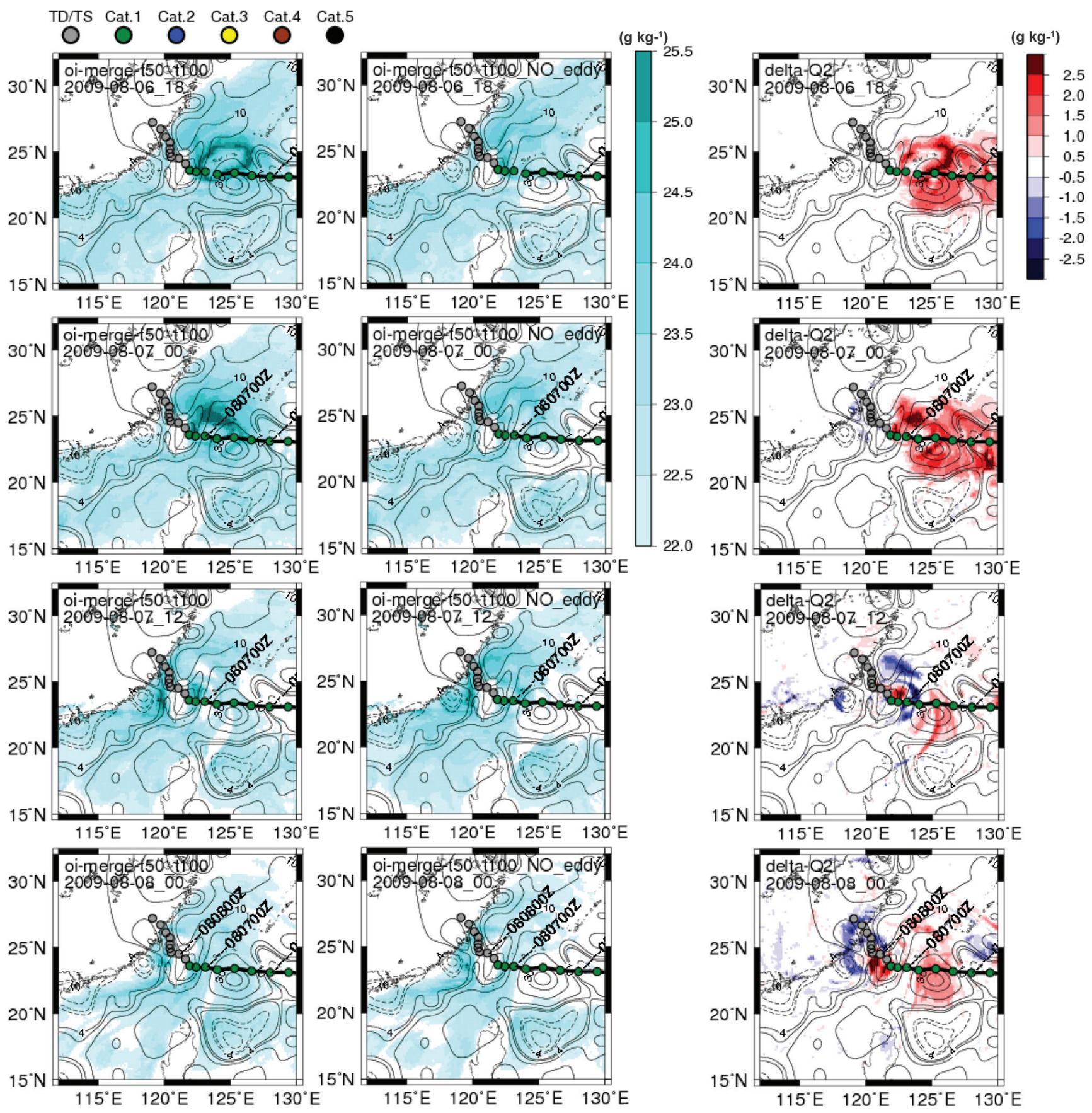

Fig. 6. Simulated water vapour mixing ratio at $2 \mathrm{~m}$ (unit: $\mathrm{g} \mathrm{kg}^{-1}$ ) from the WRF numerical experiments between 6 and 8 August 2009 for the 'with eddy' (left) and 'without eddy' (middle). The difference between the two runs is illustrated in (right). 


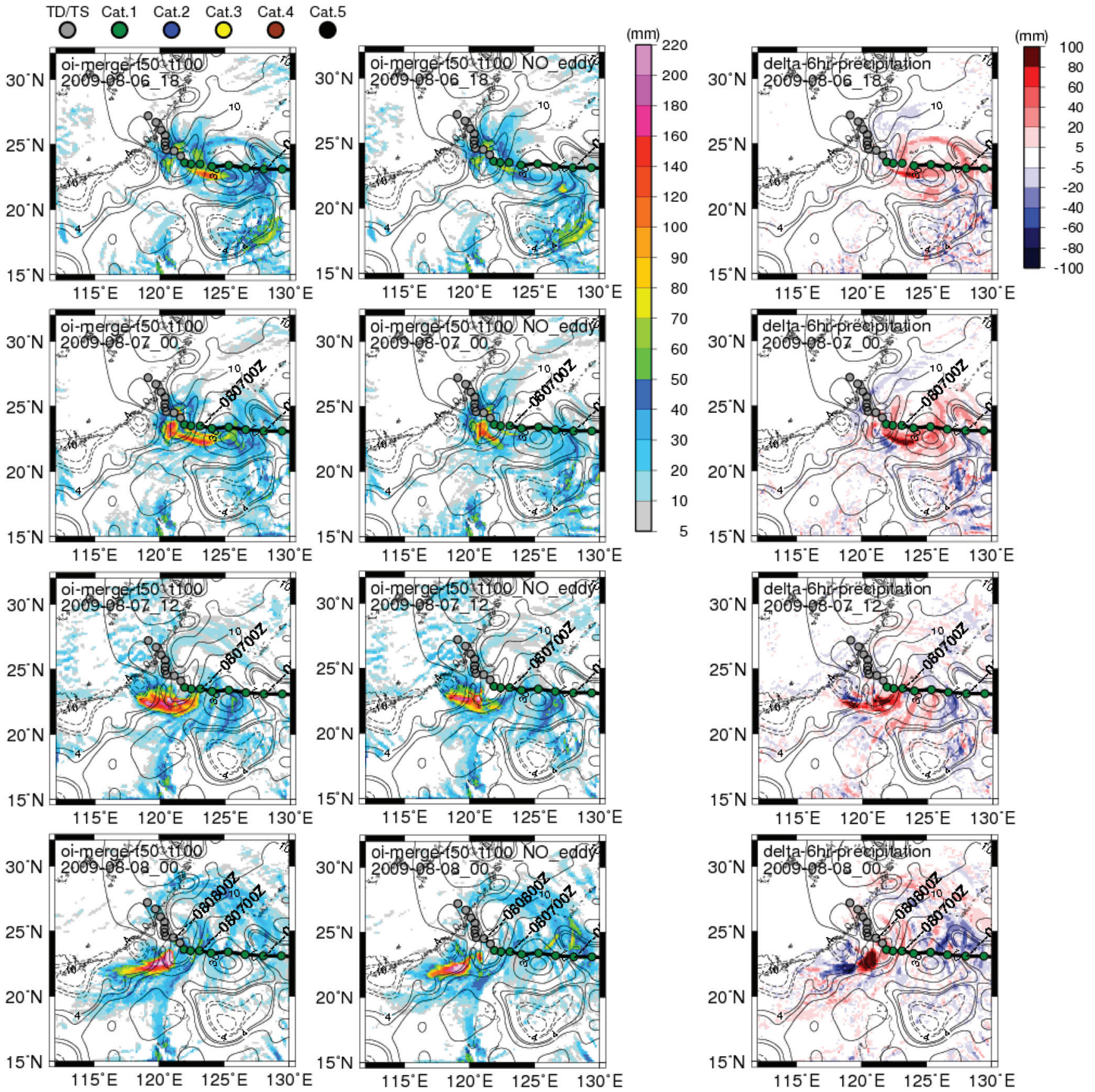

Fig. 7. Simulated $6 \mathrm{hr}$ total precipitation from the WRF numerical experiments between 6 and 8 August 2009 for the 'with eddy' (left) and 'without eddy' (middle). The difference between the two runs is illustrated in (right).

was observed. As compared to the situation on 6 August, the increase in precipitation was more intense and localised, i.e., according to the convective structure of Morakot as it made landfall. Overall, it is found that the difference between the 'with eddy' and 'without eddy' runs does not change the characteristics of the convective structure and activity. Rather, the impact is attributable to a general increase in precipitation by about $10 \%$.

Exploring the possible physical reasons for the increase in precipitation, the numerical simulations suggest that as the during-storm SST over the warm ocean eddy was warmer, there was an increase in latent heat and water vapour supply to favour the convective activity. It is also possible that as the presence of a warm ocean eddy helped to increase the intensity of Morakot (Fig. 8), the maximum wind increased and could entrain more south-western monsoonal moisture and favour precipitation as Morakot approached Taiwan on 7 - 8 August (Fig. 7). 


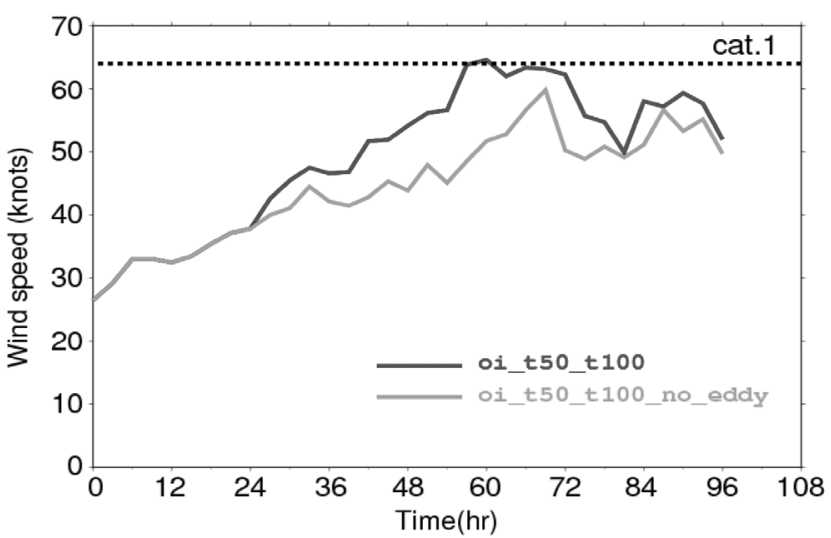

Fig. 8. Simulated intensity of Morakot (in wind speed) from the WRF numerical experiments for 'with eddy' (black curve) and 'without eddy' (gray curve) runs.

\section{DISCUSSION AND CONCLUSIONS}

The observational and numerical results presented in this research suggest a supportive role wherein a giant warm ocean eddy played demonstrable role developing Morakot's intensification and rainfall as it traveled over the Pacific between 5 and 6 August. The presence of the warm ocean eddy does not change the structure or characteristic of Morakot. Rather, it served to provide additional water vapour and latent heat supply to increase Morakot's intensity and precipitation. A comparison between the numerical simulations of the 'with eddy' and 'without eddy' runs using WRF suggests a $\sim 10 \%$ increase in rainfall as Morakot transversed the warm ocean eddy on 6 August 2009. In the WRF simulations, it was also found that Morakot's intensity increased due to the suppression of the typhoon's self-induced ocean cooling negative feedback in the 'with eddy' run. It is possible that this increase in intensity and wind speed can have higher chance to entrain more SW monsoonal moisture to enhance precipitation of Morakot between 7 and 8 August.

While this study provides a preliminary investigation on the possible role a warm ocean eddy played in Morakot's rainfall and intensity, there remains to be more scientific issues for further investigation. For example, though the air-sea flux supply over the warm ocean eddy increased by $\sim 200 \%$, Morakot only peaked at category- 2 . This might be associated with Morakot's storm structure, i.e., a weak inner core but large and asymmetric outer rain bands. In other words, it is possible that the flux supply may contribute more to large outer rain bands instead of contributing to an inner core intensity. This interplay between an ocean's flux supply and storm structure may cause a difference in an ocean's contribution to a cyclone's rainfall and intensity for different storms. It would thus be an interesting scientific issue to quantify future investigations using a fully coupledphysics typhoon-ocean model under different storm structure scenarios.
Acknowledgements The authors wish to thank Ms. ChunChi Lien and Ms. Rebecca Wu for WRF model simulation. This work is supported by the National Science Council, Taiwan through NSC98-2611-M-002-014-MY3W and NSC 100-2111-M-002-001 and National Taiwan University project number 10R70803.

\section{REFERENCES}

Alpers, W., J. P. Chen, C. J. Pi, and I. I. Lin, 2010: On the origin of atmospheric frontal lines off the east coast of Taiwan observed on spaceborne synthetic aperture radar images. Mon. Weather Rev., 138, 475-496, doi: 10.1175/2009MWR2987.1. [Link]

Alpers, W., J. P. Chen, I. I. Lin, and C. C. Lien, 2007: Atmospheric fronts along the east coast of Taiwan studied by ERS synthetic aperture radar images. J. Atmos. Sci., 64, 922-937, doi: 10.1175/JAS3863.1. [Link]

Black, P. G., E. A. D'Asaro, T. B. Sanford, W. M. Drennan, J. A. Zhang, J. R. French, P. P. Niiler, E. J. Terrill, and E. J. Walsh, 2007: Air-sea exchange in hurricanes: Synthesis of observations from the coupled boundary layer air-sea transfer experiment. Bull. Amer. Meteorol. Soc., 88, 357-374, doi: 10.1175/BAMS-88-3-357. [Link]

Chen, Y. L. L., H. Y. Chen, I. I. Lin, M. A. Lee, and J. Chang, 2007: Effects of cold eddy to phytoplankton production and assemblages in Luzon Strait bordering the South China Sea. J. Oceanogr., 63, 671-683.

D’Asaro, E., P. Black, L. Centurioni, P. Harr, S. Jayne, I. I. Lin, C. Lee, J. Morzel, R. Mrvaljevic, P. Niiler, L. Rainville, T. Sanford, and T.-Y. D. Tang, 2011: TyphoonOcean Interaction in the Western North Pacific - Part 1. Oceanography, 24, 20-27, in press.

Emanuel, K. A., 1995: Sensitivity of tropical cyclones to surface exchange coefficients and a revised steadystate model incorporating eye dynamics. J. Atmos. Sci., 52, 3969-3976, doi: 10.1175/1520-0469(1995)052<39 69:SOTCTS>2.0.CO;2. [Link]

Emanuel, K. A., 1999: Thermodynamic control of hurricane intensity. Nature, 401, 665-669, doi: 10.1038/44326. [Link]

Emanuel, K. A., C. DesAutels, C. Holloway, and R. Korty, 2004: Environmental control of tropical cyclone intensity. J. Atmos. Sci., 61, 843-858, doi: 10.1175/1520-04 69(2004)061<0843:ECOTCI>2.0.CO;2. [Link]

Fu, L. L. and A. Cazenave, 2001: A Handbook of Techniques and Applications. Satellite Altimetry and Earth Sciences, Volume 69, Academic Press, San Diego, $463 \mathrm{pp}$.

Fu, L. L., E. J. Christensen, C. A. Yamarone Jr., M.Lefebvre, Y. Ménard, M. Dorrer, and P. Escudier, 1994: TOPEX/ POSEIDON mission overview. J. Geophys. Res., 99, 24369-24381, doi: 10.1029/94JC01761. [Link] 
Goni, G. J. and J. A. Trinanes, 2003: Ocean thermal structure monitoring could aid in the intensity forecast of tropical cyclones. Eos, Trans., AGU, 84, 573-580, doi: 10.1029/2003EO510001. [Link]

Goni, G. J., M. DeMaria, J. Knaff, C. Sampson, I. Ginis, F. Bringas, A. Mavume, C. Lauer, I. I. Lin, M. M. Ali, P. Sandery, S. Ramos-Buarque, K. Kang, A. Mehra, E. Chassignet, and G. Halliwell, 2009: Applications of satellite-derived ocean measurements to tropical cyclone intensity forecasting. Oceanography, 22, 190197, doi: 10.5670/oceanog.2009.78. [Link]

Holliday, C. R. and A. H. Thompson, 1979: Climatological characteristics of rapidly intensifying typhoons. Mon. Weather Rev., 107, 1022-1034, doi: 10.1175/1520-049 3(1979) 107<1022:CCORIT>2.0.CO;2. [Link]

Hong, X., S. W. Chang, S. Raman, L. K. Shay, and R. Hodur, 2000: The interaction between Hurricane Opal (1995) and a warm core ring in the Gulf of Mexico. Mon. Weather Rev., 128, 1347-1365, doi: 10.1175/1520-04 93(2000)128<1347:TIBHOA>2.0.CO;2. [Link]

Hong, C. C., M. Y. Lee, H. H. Hsu, and J. L. Kuo, 2010: Role of submonthly disturbance and 40-50-day ISO on the extreme rainfall event associated with typhoon Morakot (2009) in southern Taiwan. Geophys. Res. Lett., 37, L08805, doi: 10.1029/2010GL042761. [Link]

Huang, C. Y., C. S. Wong, and T. C. Yeh, 2011: Extreme rainfall mechanisms exhibited by Typhoon Morakot (2009). Terr. Atmos. Ocean. Sci., 22, 613-632, doi: 10. 3319/TAO.2011.07.01.01(TM). [Link]

Hwang, C., C. R. Wu, and R. Kao, 2004: TOPEX/Poseidon observations of mesoscale eddies over the subtropical countercurrent: Kinematic characteristics of an anticyclonic eddy and a cyclonic eddy. J. Geophys. Res., 109, C08013, doi: 10.1029/2003JC002026. [Link]

Kidder, S. Q. and T. H. Vonder Haar, 1995: Satellite Meteorology. Academic Press, 466 pp.

Lee, I. H., W. S. Chuang, and D. P. Wang, 2003: Structure and propagation of a large cyclonic eddy in the western North Pacific from analysis of XBT and altimetry data and numerical simulation. Terr. Atmos. Ocean. Sci., 14, 183-200.

Lin, I. I., 2012: Typhoon-induced phytoplankton blooms and primary productivity increase in the western north Pacific subtropical ocean. J. Geophys. Res., in press.

Lin, I. I., W. T. Liu, C. C. Wu, J. C. H. Chiang, and C. H. Sui, 2003a: Satellite observations of modulation of surface winds by typhoon-induced upper ocean cooling. Geophys. Res. Lett., 30, 1131, doi: 10.1029/2002GL01 5674. [Link]

Lin, I. I., W. T. Liu, C. C. Wu, G. T. F. Wong, C. Hu, Z. Chen, W. D. Liang, Y. Yang, and K. K. Liu, 2003b: New evidence for enhanced ocean primary production triggered by tropical cyclone. Geophys. Res. Lett., 30, 1718, doi: 10.1029/2003GL017141. [Link]
Lin, I. I., C. C. Wu, K. A. Emanuel, I. H. Lee, C. R. Wu, and I. F. Pun, 2005: The interaction of supertyphoon Maemi (2003) with a warm ocean eddy. Mon. Weather Rev., 133, 2635-2649, doi: 10.1175/MWR3005.1. [Link]

Lin, I. I., C. C. Wu, I. F. Pun, and D. S. Ko, 2008: Upperocean thermal structure and the western North Pacific category 5 typhoons. Part I: Ocean features and the category 5 typhoons' intensification. Mon. Weather Rev., 136, 3288-3306, doi: 10.1175/2008MWR2277.1. [Link]

Lin, I. I., C. H. Chen, I. F. Pun, W. T. Liu, and C. C. Wu, 2009a: Warm ocean anomaly, air sea fluxes, and the rapid intensification of tropical cyclone Nargis (2008). Geophys. Res. Lett., 36, L03817, doi: 10.1029/2008GL 035815. [Link]

Lin, I. I., I. F. Pun, and C. C. Wu, 2009b: Upper-ocean thermal structure and the western North Pacific category 5 typhoons. Part II: Dependence on translation speed. Mon. Weather Rev., 137, 3744-3757, doi: 10.1175/2009MWR2713.1. [Link]

Mellor, G. L. and T. Yamada, 1982: Development of a turbulence closure model for geophysical fluid problems. Rev. Geophys., 20, 851-875, doi: 10.1029/RG02 0i004p00851. [Link]

Powell, M. D., P. J. Vickery, and T. A. Reinhold, 2003: Reduced drag coefficient for high wind speeds in tropical cyclones. Nature, 422, 279-283, doi: 10.1038/nature 01481. [Link]

Pun, I. F., I. I. Lin, C. R. Wu, D. S. Ko, and W. T. Liu, 2007: Validation and application of altimetry-derived upper ocean thermal structure in the western North Pacific Ocean for typhoon-intensity forecast. IEEE Trans. Geosci. Remote Sensing, 45, 1616-1630, doi: 10.1109/ TGRS.2007.895950. [Link]

Pun, I. F., Y. T. Chang, I. I. Lin, T. Y. Tang, and R. C. Lien, 2011: Typhoon-ocean interaction in the western north Pacific - Part 2. Oceanography, 24, 28-37, in press.

Price, J. F., 1981: Upper ocean response to a hurricane. $J$. Phys. Oceanogr., 11, 153-175, doi: 10.1175/1520-048 5(1981)011<0153:UORTAH>2.0.CO;2. [Link]

Price, J. F., 2009: Metrics of hurricane-ocean interaction: Vertically-integrated or vertically-averaged ocean temperature? Ocean Sci., 5, 351-368, doi: 10.5194/os-5351-2009. [Link]

Qiu, B., 1999: Seasonal eddy field modulation of the North Pacific Subtropical Countercurrent: TOPEX/Poseidon observations and theory. J. Phys. Oceanogr., 29, 24712486, doi: 10.1175/1520-0485(1999)029<2471:SEFM OT>2.0.CO;2. [Link]

Roemmich, D. and J. Gilson, 2001: Eddy transport of heat and thermocline waters in the north pacific: A key to interannual/decadal climate variability? J. Phys. Oceanogr., 13, 675-687, doi: 10.1175/1520-0485(2001)031 
$<0675$ :ETOHAT>2.0.CO;2. [Link]

Shay, L. K., G. J. Goni, and P. G. Black, 2000: Effects of a warm oceanic feature on Hurricane Opal. Mon. Weather Rev., 128, 1366-1383, doi: 10.1175/1520-0493(200 0) $128<1366$ :EOAWOF>2.0.CO;2. [Link]

Stephens, C., J. I. Antonov, T. P. Boyer, M. E. Conkright, R. A. Locarnini, T. D. O'Brien, and H. E. Garcia, 2002: World Ocean Atlas 2001 Volume 1: Temperature. Levitus, S. (Ed.), NOAA Atlas NESDIS 49, US Government Printing Office, Washington, DC.

Tao, W. K., J. J. Shi, P. L. Lin, J. Chen, S. Lang, M. Y. Chang, M. J. Yang, C. C. Wu, C. Peters-Lidard, C. H. Sui, and B. J. D. Jou, 2011: High-resolution numerical simulation of the extreme rainfall associated with Typhoon Morakot. Part I: Comparing the impact of microphysics and PBL parameterizations with observations. Terr. Atmos. Ocean. Sci., 22, 673-696, doi: 10.3319/TAO.2011.08.26.01(TM). [Link]

Tseng, Y. H., S. Jan, D. E. Dietrich, I. I. Lin, Y. T. Chang, and T. Y. Tang, 2010: Modeled oceanic response and sea surface cooling to typhoon Kai-Tak. Terr. Atmos. Ocean. Sci., 21, 85-98, doi: 10.3319/TAO.2009.06.08. 02(IWNOP). [Link]

Wentz, F. J., C. Gentemann, D. Smith, and D. Chelton, 2000: Satellite measurements of sea surface temperature through clouds. Science, 288, 847-850, doi: 10. 1126/science. 288.5467.847. [Link]

Wu, C. C., 2001: Numerical simulation of Typhoon Gladys (1994) and its interaction with Taiwan terrain using the GFDL hurricane model. Mon. Weather Rev., 129, 1533-1549, doi: 10.1175/1520-0493(2001)129<1533: NSOTGA $>2.0 . C O ; 2$. [Link]

Wu, C.C. and Y.H. Kuo, 1999: Typhoons affecting Taiwan: Current understanding and future challenges. Bull. Amer. Meteorol.Soc., 80, 67-80, doi: 10.1175/1520-04 77(1999)080<0067:TATCUA > 2.0.CO;2. [Link]

Wu, C. C., T. H. Yen, Y. H. Kuo, and W. Wang, 2002: Rainfall simulation associated with Typhoon Herb (1996) near Taiwan. Part I: The topographic effect. Weather Forecast., 17, 1001-1015, doi: 10.1175/1520-0434(20 03)017<1001:RSAWTH $>2.0 . \mathrm{CO} ; 2$. [Link]

Wu, C. C., C. Y Lee, and I. I. Lin, 2007: The effect of the ocean eddy on tropical cyclone intensity. J. Atmos. Sci., 64, 3562-3578, doi: 10.1175/JAS4051.1. [Link]

Yang, M. J., T. C. Chen Wang, Y. Zhang, and C. Y. Weng, 2011: Momentum budget evolution of Typhoon Nari (2001) during the landfall process. Terr. Atmos. Ocean. Sci., 22, 595-612, doi: 10.3319/TAO.2011.05.31.01 (TM). [Link]

Yasuda, I., K. Okuda, and M. Hirai, 1992: Evolution of a Kuroshio warm-core ring - Variability of the hydrographic structure. Deep-Sea Res., 39, S131-S161, doi: 10.1016/S0198-0149(11)80009-9. [Link]

Yen, T. H., C. C. Wu, and G. Y. Lien, 2011: Rainfall simulations of Typhoon Morakot with controlled translation speed based on EnKF data assimilation. Terr. Atmos. Ocean. Sci., 22, 647-660, doi: 10.3319/TAO.2011.07. 05.01(TM). [Link] 